\title{
Guido, Quel Gianni Ch'a Te Fu L'Altr' Ieri • Gianni Alfani
}

Guido, Gianni that saw you yesterday

Or the other day; if you like, you may laugh me down,

But there's a young girl in Pisa, where the town

Is split by the Arno, who's a frown

Against love, and carries a dagger.

She asked me if you were fit (him who hath slain her)

To serve, and how far, the ladies you kill,

If she came, let us say, in such a way with him

That he alone, and Mr. Gaultier were aware.

So that the family: bent on slaughter

Could at most do naught, or no more than

Call mate (check-mate, that is) from afar.

I said, on my own, that you, and no sham,

Had your pouch full of munition,

And would indubitably, free her from the embarrassing position.

(from the Italian, ca. 1927-1934) 